\title{
Natural Diet, Feeding and Predatory Activity of the Crabs Callinectes arcuatus and C. toxotes (Decapoda, Brachyura, Portunidae)
}

\author{
R. K. G. Paul \\ Department of Marine Biology, University of Liverpool, Port Erin, Isle of Man, Great Britain \\ and \\ Centro de Ciencias del Mar y Limnologia, Estacion Mazatlan, Unam, A.P. 811, Mazatlan, Sinaloa, Mexico
}

\begin{abstract}
The natural diet of Callinectes arcuatus Ordway in the Huizache-Caimanero lagoon system (W. Mexico) was determıned and several aspects of its feedıng and predatory activity were investigated. Limited observations were also made on the diet of C. toxotes Ordway. The diets of the two crabs were similar, but that of $C$. arcuatus appeared more varied; it consisted mannly of bivalve molluscs, crabs and fish. Differences in the diet of $C$. arcuatus in different areas of the lagnon system and at different times of the year reflected differences in prey availability rather than in prey selection. Small crabs (below $60 \mathrm{~mm}$ breadth) were basically detritivores and scavengers, whilst larger crabs were scavengers and predatory feeders. They were not found to be major predators of penaet shrmp. and $C$. arcuatus was shown not to be an efficient predator of highly mobile animals such as shrimp. Feeding occurred mainly at night, especially around dusk.
\end{abstract}

\section{INTRODUCTION}

The Huizache-Caimanero lagoon system, like most others on the Pacific Coast of Mexico, supports an important seasonal fishery for penaeid shrimp (Edwards, 1977, 1978a, b). Crabs have often been regarded locally as major predators of shrimp, but no study known to this author has been conducted to investigate this assumption. Paul (in press) described the distribution and general ecology of Callinectes arcuatus and $C$. toxotes in the lagoon system. The present paper deals with the natural diet and some aspects of feeding behaviour, principally of $C$. arcuatus, and evaluates the trophic relationships between crabs and shrimp.

The lagoon system is located between $22^{\circ} 48^{\prime}-$ $23^{\circ} 06^{\prime} \mathrm{N}$ and $106^{\circ} 00^{\prime}-106^{\circ} 16^{\prime} \mathrm{W}, 25 \mathrm{~km}$ south of the city of Mazatlan, in the State of Sinaloa on the Pacific coast of Mexico. Its geography and general conditions have been described by several authors (Edwards, 1977. 1978a; Warburton, 1978, 1979; Paul, in press); its main features are shown in Fig. 1

\section{MATERIALS AND METHODS}

\author{
Analysis of Foregut Contents
}

Random sub-samples were taken from routine biweekly trawl samples (Paul, in press) of Callinectes arcuatus Ordway and $C$. toxotes Ordway from the Huizache-Caimanero lagoon system between February 1975 and June 1976 for analysis of foregut contents. All the crabs were killed immediately upon capture and preserved in 5-10\% formalin solution.

Upon return to the laboratory the foreguts of the crabs were removed by dissection and their exteriors washed in water, holding both ends closed with forceps. Each foregut was then opened and its contents washed out into a Petri dish with water The gut contents were then identified, separated into taxa and dried to constant weight at $80^{\circ} \mathrm{C}$, since Steigenberger and Larkin (1974) reported that initial hydrolysis of food in stomachs leads to inaccuracies in wet weights. Only foreguts estimated to be over $50 \%$ full were used in the analysis. 


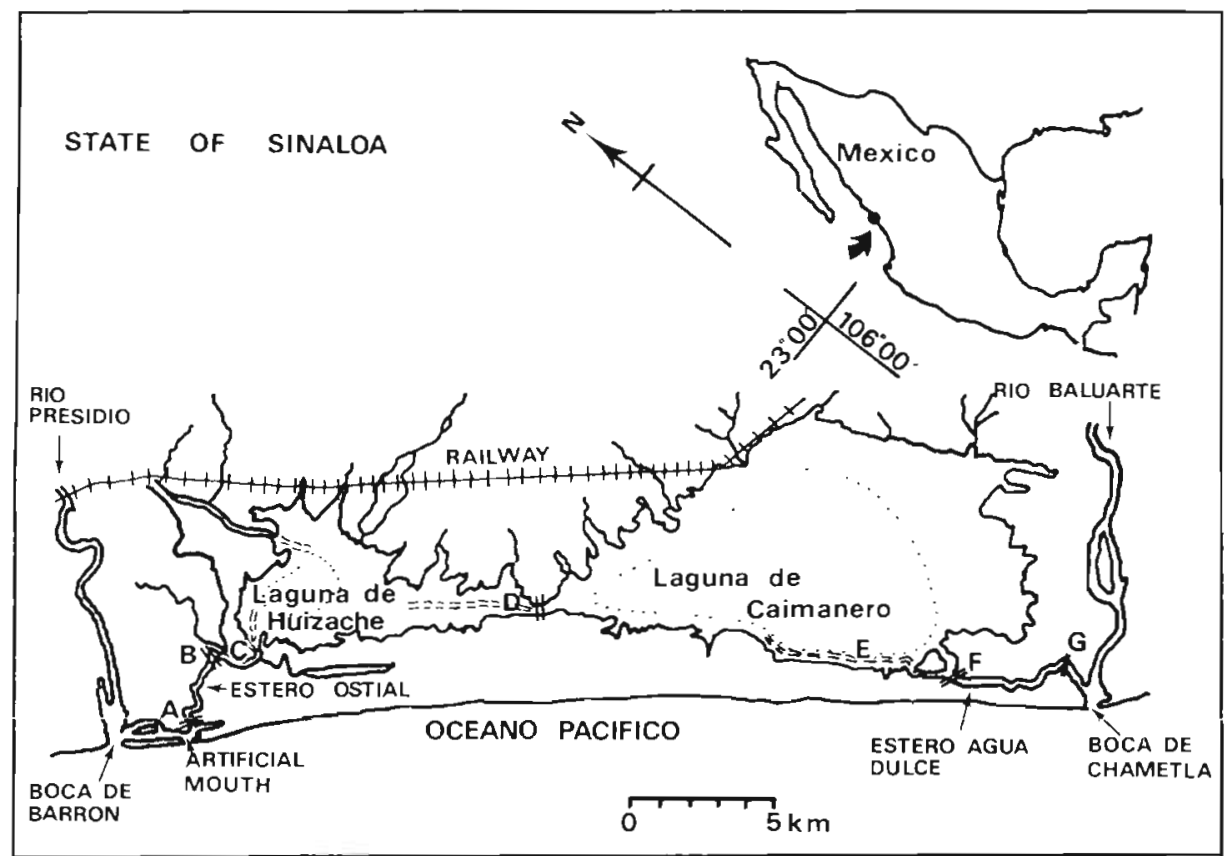

Fig. 1. Map of Huizache-Caimanero lagoon system. Mean minimum limits of the lagoons (late dry season) are dotted. Canals are shown by a broken lines. Important sampling stations: A, Tapo Botadero; B. Tapo Ostial; C. Las Garzas; D. Tapo Pozo de la Hacienda; E, El Tanque Canal; F. Tapo Caimanero; G, Tapo Agua Dulce
The gravimetric and frequency of occurrence methods (Hynes, 1950; Windell, 1968) were used to analyse the gut contents. In the former, the dry weight of each food item is expressed as a percentage of the total dry weight of all food items in the sample in the latter, the number of foreguts in which each food item occurred is expressed as a percentage of the total number of foreguts examined (frequency per 100 foreguts).

\section{Predation on Live Shrimps and Feeding Activity of Callinectes arcuatus}

Two separate experiments were carried out to investigate the predation of Callinectes arcuatus on Penaeus vannamei. In the first experiment 7 glass tanks, each measuring $70 \times 35 \times 35 \mathrm{~cm}$ (height) and containing sand to a depth of $10 \mathrm{~cm}$ and lagoon water (salinity $=30 \% \mathrm{~S}$, temperature $=29^{\circ} \mathrm{C} \pm 2 \mathrm{C}^{\circ}$ ) to a total depth of $30 \mathrm{~cm}$, were used. The water in each tank was aerated and all tanks were covered with glass lids. Four shrimps (total lengths $90-130 \mathrm{~mm}$ ) and $1 \mathrm{crab}$ (carapace breadths $64-120 \mathrm{~mm}$ ) were introduced to each of 6 tanks, and 4 shrimps were placed in a control tank. The shrimps used were freshly brought from the lagoon, but the crabs were acclimated in the laboratory under different feeding regimes for $7 \mathrm{~d}$ prior to the start of the experiment. During the period of acclimation 2 crabs were starved and 4 were fed daily on peeled shrimp abdomen. Of the fed crabs, 1 was fed $1 \mathrm{~g}$ of shrimp daily before and throughout the experiment, and 1 was fed daily more shrimp than it could consume; the other 2 were not fed after the experiment had begun.

The tanks were observed frequently over a period of $5 \mathrm{~d}$, including several $2 \mathrm{~h}$ periods of continuous observation, and the number of shrimp in each tank was counted each morning when the remains of dead shrimp were removed from the tanks. At night, illumination was provided by a red light bulb so as not to affect the behaviour of the crabs and shrimps, since benthic crustaceans are relatively insensitive to red light (Goldsmith and Fernandez, 1968; Fernandez, 1973)

In the second experiment 3 tanks, 1 measuring $116 \times 25 \times 60 \mathrm{~cm}$ (height) and 2 measuring $96 \times 36 \times 46 \mathrm{~cm}$ (height), were filled with $10 \mathrm{~cm}$ of sand and diluted seawater (salinity $=34 \% \mathrm{~S}$, temperature $=27^{\circ} \mathrm{C} \pm 2 \mathrm{C}^{\circ}$ ) to total depths of $55 \mathrm{~cm}$ and $30 \mathrm{~cm}$ respectively. Ten crabs (carapace breadths 90-120 $\mathrm{mm}$ ) and 4 shrimps (total lengths $100-140 \mathrm{~mm}$ ) were introduced into the largest tank, and $1 \mathrm{crab}$ and 4 shrimps and $1 \mathrm{crab}$ and 2 shrimps, respectively, were placed in the other 2 tanks. The crabs were fed regularly on peeled shrimp abdomen up till the start of the experiment. The tanks were inspected twice daily over a period of $30 \mathrm{~d}$ and the number of shrimps in each tank counted each morning. Illumination at night was provided by a red light bulb. 
Table 1 Callinectes arcuatus and C. toxotes. Foregut contents; February 1975 to May 1976

\begin{tabular}{|c|c|c|c|c|c|}
\hline \multirow{2}{*}{\multicolumn{2}{|c|}{ Number of foreguts examined }} & \multicolumn{2}{|c|}{$\begin{array}{c}\text { C. arcuatus } \\
533\end{array}$} & \multicolumn{2}{|c|}{$\begin{array}{c}\text { C. toxotes } \\
8\end{array}$} \\
\hline & & $\begin{array}{c}\% \text { dry weight } \\
\text { of diet }\end{array}$ & $\begin{array}{c}\text { Frequency per } \\
100 \text { foreguts }\end{array}$ & $\begin{array}{l}\% \text { dry weight } \\
\text { of diet }\end{array}$ & $\begin{array}{c}\text { Frequency per } \\
100 \text { foreguts }\end{array}$ \\
\hline \multirow{3}{*}{ Molluscs: } & jalves & 26.9 & 47.6 & 59.7 & 87.5 \\
\hline & stropods & 1.0 & 10.2 & - & - \\
\hline & tal & 27.9 & & 59.7 & \\
\hline \multirow[t]{4}{*}{ Crustaceans: } & Crabs & 15.2 & 42.9 & 29.1 & 62.5 \\
\hline & Non-brachyuran decapods & 5.6 & 30.6 & - & - \\
\hline & Other crustaceans & 1.3 & 14.3 & - & - \\
\hline & Total & 22.1 & & 29.1 & \\
\hline \multicolumn{2}{|l|}{ Fish } & 16.5 & 43.9 & 3.6 & 25.0 \\
\hline \multicolumn{2}{|c|}{ Plant material } & 2.9 & 44.9 & 0.7 & 50.0 \\
\hline \multicolumn{2}{|c|}{ Polychaetes } & 1.8 & 26.6 & 0.3 & 25.0 \\
\hline \multicolumn{2}{|c|}{ Foraminiferans } & 0.1 & 10.2 & 0.1 & 37.5 \\
\hline \multicolumn{2}{|c|}{ Bryozoans } & 0.1 & 15.3 & 0.1 & 12.5 \\
\hline \multicolumn{2}{|l|}{ Sponges } & 0.1 & 13.3 & - & - \\
\hline \multicolumn{2}{|l|}{ Hydrozoans } & 0.1 & 40.8 & $\langle 0.1$ & 12.5 \\
\hline \multicolumn{2}{|l|}{ Insects } & $\langle 0.1$ & $\langle 0.1$ & - & - \\
\hline \multicolumn{2}{|l|}{ Nematodes } & $\langle 0.1$ & $\langle 0.1$ & - & - \\
\hline \multicolumn{2}{|c|}{ Unidentifiable organic material } & 14.5 & 45.9 & 2.6 & 37.5 \\
\hline \multicolumn{2}{|c|}{ Sand etc. } & 13.8 & 44.9 & 3.8 & 50.0 \\
\hline
\end{tabular}

\section{RESULTS}

\section{Analysis of Foregut Contents}

Molluscs were the most important item in the diet of Callinectes arcuatus; they constituted nearly $28 \%$ of the total dry weight of the foregut contents (Table 1). Bivalves occurred nearly 5 times as frequently as gastropods and accounted for more than 25 times as much of the dry weight of food, with Tagelus affinis being the dominant species in the former group, and Cerithidea mazatlanica in the latter. Next most abundant in the foreguts were crustaceans, particularly crabs, which together formed over $22 \%$ of the total dry weight of food. Most of the crab remains were those of Callinectes spp., but remains of Gecarcinus sp. and Cardisoma crassum were also found in large quantities. Non-brachyuran decapods occurred less frequently than crabs and constituted a much smaller proportion of the mass of food, consisting chiefly of the remains of penaeid and palaemonid shrimps (Penaeus spp. and Macrobrachium spp. respectively); remains of the burrowing shrimp Callianassa sp. were much less common. Most of the other crustacean remains found in the foregut were amphipods (Corophium spp.) and cumaceans, but these occurred much less frequently than decapods and accounted for only about $1 \%$ of the weight of food. Results for both weight of food and frequency of occurrence give fish a rather higher rating ( $16.5 \%$ of the total dry weight of food) than crabs but less than the total Decapoda. Fish remains consisted mainly of Lile stolifera (sardine), Anchoa panamensis (anchovy), Diapterus peruvianus (mojarra) and Gerres cinereus; those of other fish such as Galeichthys caerulescens (catfish) and Mugil spp. (mullet) were less common. Plant material, consisting mainly of Ruppia maritima, Salicornia sp., Cladophora sp. and Enteromorpha sp., was present in $44.9 \%$ of the foreguts examined but only in very small quantities. Polychaete remains were fairly common in the foreguts examined (including Polydora sp.) but constituted less than $2 \%$ of the total foregut contents. Foraminiferans, bryozoans, sponges and hydrozoans were all present in a fairly large number of foreguts but they each constituted $0.1 \%$ or less of the total foregut contents. The state of mechanical and chemical breakdown of the food is reflected by the fact that nearly half the foreguts examined contained unidentifiable organic debris which, in bulk, approached the importance of identifiable remains of fish or crabs. Sand and mud were present in many foreguts in quite large quantities.

The results for Callinectes toxotes (Table 1), although based on a small sample, show a much greater dominance of bivalve molluscs in the foregut contents, with crab remains - the only other important item - consisting about half the weight of the bivalves. These 2 categories accounted for about $90 \%$ of the foregut contents, fish constituting only $4 \%$ of the total dry weight; other foods were present in negligible quantities. Gastropods and shrimps were not recorded. 
Table 2. Callinectes arcuatus. Foregut contents of individuals from different areas of the lagoon system, expressed as percentage dry weight of food; February 1975 to May 1976

\begin{tabular}{|c|c|c|c|c|c|}
\hline & $\begin{array}{c}\text { TapoBotadero } \\
\text { (Huizache) }\end{array}$ & $\begin{array}{l}\text { Las Garzas } \\
\text { (Huizache) }\end{array}$ & $\begin{array}{c}\text { El Tanque } \\
\text { (Caimanero) }\end{array}$ & $\begin{array}{c}\text { Tapo Calmanero } \\
\text { (Caimanero) }\end{array}$ & $\begin{array}{c}\text { Tapo Agua Dulce } \\
\text { (Caimanero) }\end{array}$ \\
\hline Molluscs: Bivalves & 5.2 & 19.1 & 35.4 & 34.1 & 43.5 \\
\hline Gastropods & - & 0.4 & 1.1 & 1.1 & 0.7 \\
\hline Total & 5.2 & 19.5 & 36.5 & 35.2 & 44.2 \\
\hline \multirow[t]{4}{*}{ Crustaceans: Crabs } & 10.7 & 25.9 & 8.1 & 10.4 & 5.6 \\
\hline & 19.6 & 6.2 & 5.1 & 3.9 & 1.8 \\
\hline & 23.9 & 0.6 & 1.5 & 0.4 & 0.2 \\
\hline & 54.2 & 32.7 & 14.7 & 14.7 & 7.6 \\
\hline Fish & 1.9 & 21.9 & 9.8 & 10.1 & 23.9 \\
\hline Plant material & 7.2 & 1.3 & 4.1 & 3.4 & 4.9 \\
\hline Polychaetes & 14.7 & 0.9 & 1.9 & 2.5 & 0.6 \\
\hline Foraminiferans & $\langle 0.1$ & 0.2 & $<0.1$ & $<0.1$ & 0.1 \\
\hline Bryozans & $\langle 0.1$ & $<0.1$ & - & $<0.1$ & - \\
\hline Sponges & - & $\langle 0.1$ & $<0.1$ & 02 & $0 ?$ \\
\hline Hydrozoans & 0.6 & 0.1 & $<0.1$ & $<0.1$ & $\langle 0.1$ \\
\hline Insects & - & $\langle 0.1$ & - & - & 0.2 \\
\hline Nematodes & - & $<0.1$ & - & - & - \\
\hline Unıdentifiable organic material & 3.4 & 12.5 & 16.7 & 19.5 & 8.6 \\
\hline Sand etc. & 12.7 & 10.8 & 16.2 & 14.3 & 9.7 \\
\hline Number of crabs & 12 & 165 & 183 & 106 & 67 \\
\hline
\end{tabular}

Table 3. Callinectes arcuatus. Foregut contents of individuals from Huizache lagoon at different times of the year, expressed as percentage dry weight of food; February 1975 to May 1976

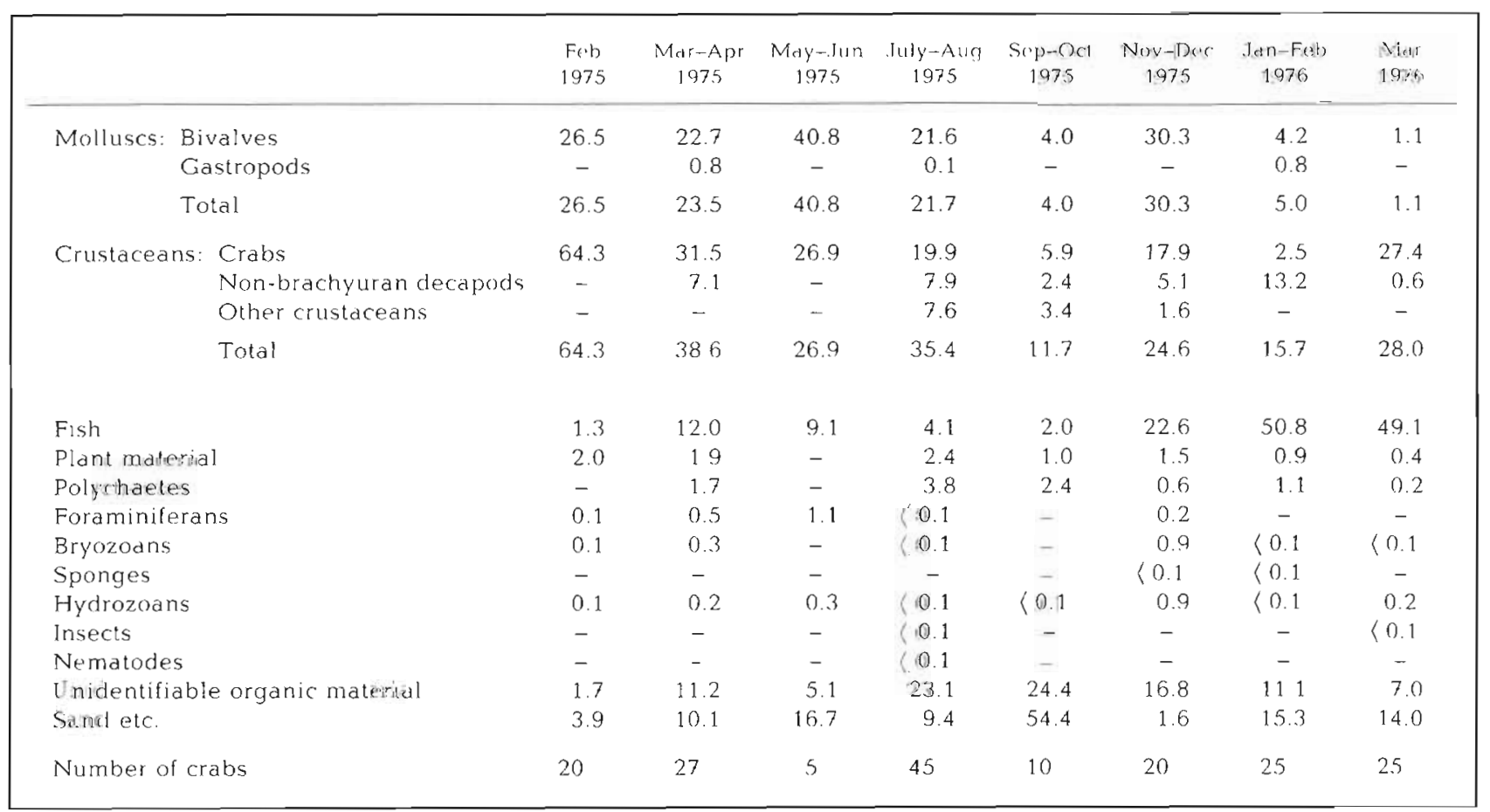


Table 4. Callinectes arcuatus. Foregut contents of individuals from Caimanero lagoon at different times of the year, expressed as percentage dry weight of food; February 1975 to May 1976

\begin{tabular}{|c|c|c|c|c|c|c|c|c|c|}
\hline & $\begin{array}{l}F(b) \\
1975\end{array}$ & $\begin{array}{c}\text { Mar-Apr } \\
1975\end{array}$ & $\begin{array}{c}\text { Mey-Jun } \\
1975\end{array}$ & $\begin{array}{c}\text { Jul-Aug } \\
1975\end{array}$ & $\begin{array}{c}\text { Sep-Ort } \\
1975\end{array}$ & $\begin{array}{c}\text { Nov-Der } \\
1975\end{array}$ & $\begin{array}{c}I_{a n}-F_{(\cdot b)} \\
1976\end{array}$ & $\begin{array}{l}M a r \\
1976\end{array}$ & $\begin{array}{l}\text { MaY } \\
1976\end{array}$ \\
\hline $\begin{aligned} & \text { Molluscs: } \text { Bivalves } \\
& \text { Gastropods }\end{aligned}$ & $\begin{array}{l}34.1 \\
-\end{array}$ & $\begin{array}{r}17.4 \\
0.9\end{array}$ & $\begin{array}{r}20.6 \\
2.5\end{array}$ & $\begin{array}{c}25.7 \\
-\end{array}$ & $\begin{array}{r}33.0 \\
5.4\end{array}$ & $\begin{array}{c}79.3 \\
-\end{array}$ & $\begin{array}{r}62.1 \\
0.7\end{array}$ & 31.7 & $\begin{array}{l}2.1 \\
2.0\end{array}$ \\
\hline Total & 34.1 & 18.3 & 23.1 & 25.7 & 38.4 & 79.3 & 62.8 & 31.7 & 4.1 \\
\hline $\begin{aligned} \text { Crustaceans: } & \text { Crabs } \\
& \text { Non-brachyuran decapods } \\
& \text { Other crustaceans }\end{aligned}$ & $\begin{array}{c}21.4 \\
- \\
-\end{array}$ & $\begin{array}{r}16.0 \\
8.6 \\
0.3\end{array}$ & $\begin{array}{r}12.3 \\
2.5 \\
3.7\end{array}$ & $\begin{array}{l}8.6 \\
7.5 \\
0.6\end{array}$ & $\begin{array}{l}9.4 \\
8.1 \\
1.1\end{array}$ & $\begin{array}{l}3.3 \\
0.1 \\
-\end{array}$ & $\begin{array}{l}2.7 \\
2.1 \\
0.5\end{array}$ & $\begin{array}{l}3.0 \\
0.3 \\
0.4\end{array}$ & $\begin{array}{l}6.2 \\
- \\
-\end{array}$ \\
\hline Total & 21.4 & 24.9 & 18.5 & 16.7 & 18.6 & 3.4 & 5.3 & 3.7 & 6.2 \\
\hline Fish & 16.2 & 25.7 & 11.4 & 11.3 & 7.7 & 1.5 & 0.5 & 17.6 & 62.8 \\
\hline Plant material & 1.1 & 1.6 & 4.8 & 3.6 & 4.7 & 5.8 & 1.0 & 0.3 & 1.9 \\
\hline Polychaetes & 3.5 & 0.6 & 2.5 & 4.0 & 0.8 & 0.3 & 1.0 & - & - \\
\hline Foraminiferans & 0.2 & 0.3 & 0.1 & $\langle 0.1$ & - & $<0.1$ & 0.1 & - & 0.3 \\
\hline Bryozoans & - & 0.3 & 0.2 & 0.1 & - & - & - & - & - \\
\hline Sponges & - & $\langle 0.1$ & - & - & $\langle 0.1$ & $\langle 0.1$ & 0.5 & $\langle 0.1$ & - \\
\hline Hydrozoans & 0.2 & 0.5 & 0.5 & 0.2 & $<0.1$ & $\langle 0.1$ & 0.2 & $<0.1$ & - \\
\hline Insects & - & 0.2 & - & - & 0.2 & - & - & - & - \\
\hline Nematodes & - & - & - & - & - & - & - & - & - \\
\hline Unidentifiable organic material & 19.6 & 19.2 & 30.7 & 23.0 & 19.9 & 4.7 & 20.5 & 25.6 & 2.8 \\
\hline Sand etc. & 3.7 & 8.4 & 8.1 & 15.5 & 9.8 & 4.9 & 8.1 & 21.0 & 21.9 \\
\hline Number of crabs & 10 & 34 & 85 & 76 & 58 & 27 & 30 & 20 & 16 \\
\hline
\end{tabular}

Table 5. Callinectes arcuatus. Foregut contents of 4 size-classes from Huizache and Caimanero lagoons, expressed as percentage dry weight of food; February 1975 to May 1976

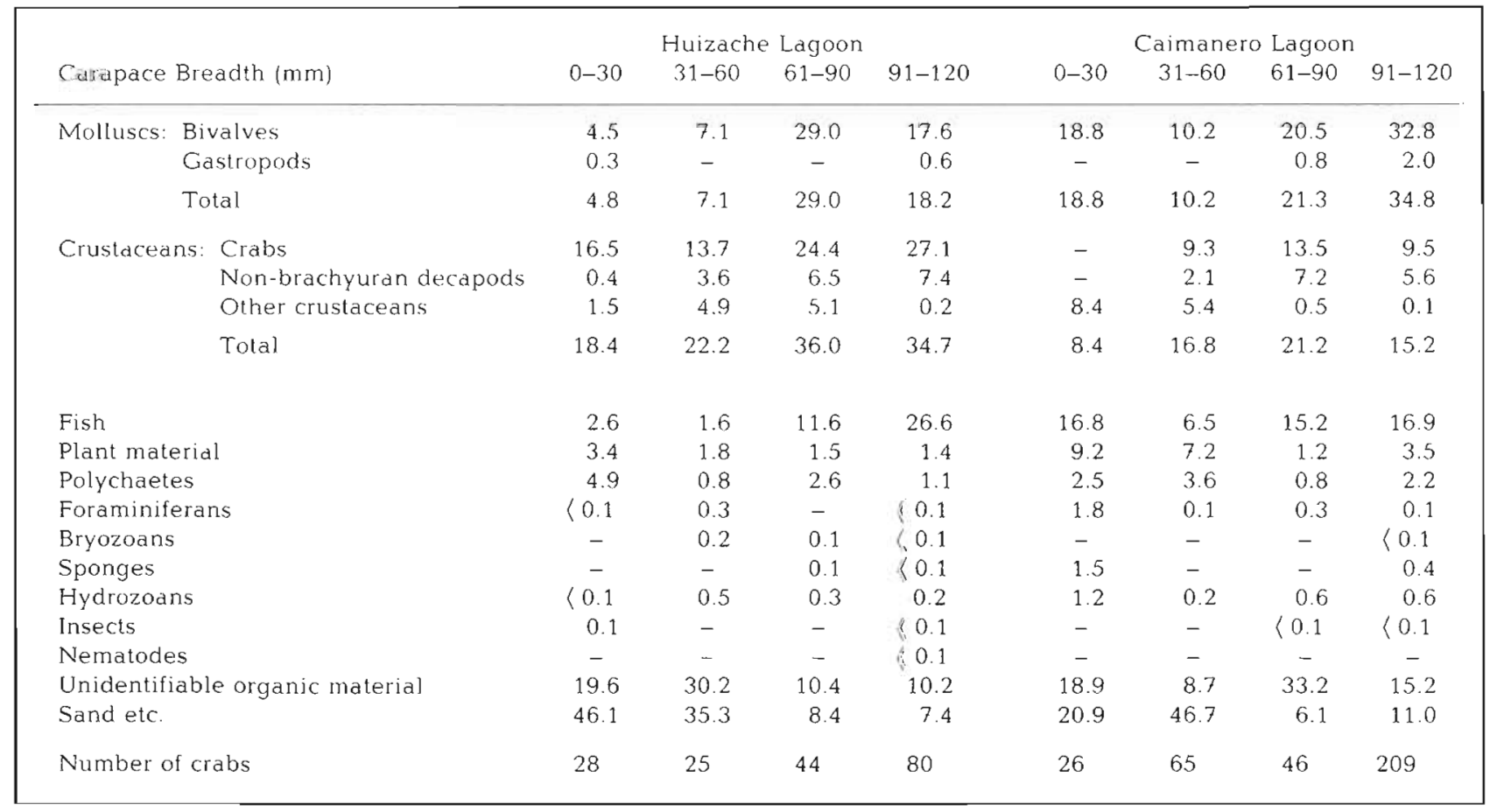


The sample size for $C$. toxotes, however, was too small to permit useful analysis of foregut contents with respect to area, season and size of crab.

In both species, recently moulted crabs had foreguts full of carapace fragments and inorganic debris. It is assumed that this material was ingested after moulting; these specimens were not used in the analysis of foregut contents.

Within the lagoon system the diet of Callinectes arcuatus varied considerably (Table 2). Mollusc remains were much more common in foregut samples from Caimanero stations than from Huizache stations; the reverse is true for crustacean remains. The most marked differences occurred between stations in mid estero, with molluscs about 8 times as important at Tapo Agua Dulce than at Tapo Botadero, and crustaceans about 7 times as important at Tapo Botadero than at Tapo Agua Dulce. The bivalve Tagelus affinis was
Botadero where they constituted nearly $15 \%$ of the foregut contents. Other dietary components were found in similar and very small quantities at all stations.

Some seasonal variation in the foregut contents was detected for Callinectes arcuatus in Huizache and Caimanero (Tables 3 and 4). Bivalves were consumed throughout the whole period but in terms of weight were most important as food in Caimanero between November and February, and in Huizache between February and August and during November and December. Gastropods were never common in the foregut contents. Crustacean remains were most important in samples from Huizache between February and August and in Caimanero between February and October. Fish remains were most abundant in foregut samples from Huizache between November and March and in Caimanero between February and May. Other

Table 6. Numbers of penaeid shrimp killed by Callinectes arcuatus over (a) a $5 \mathrm{~d}$ period, (b) a $30 \mathrm{~d}$ period

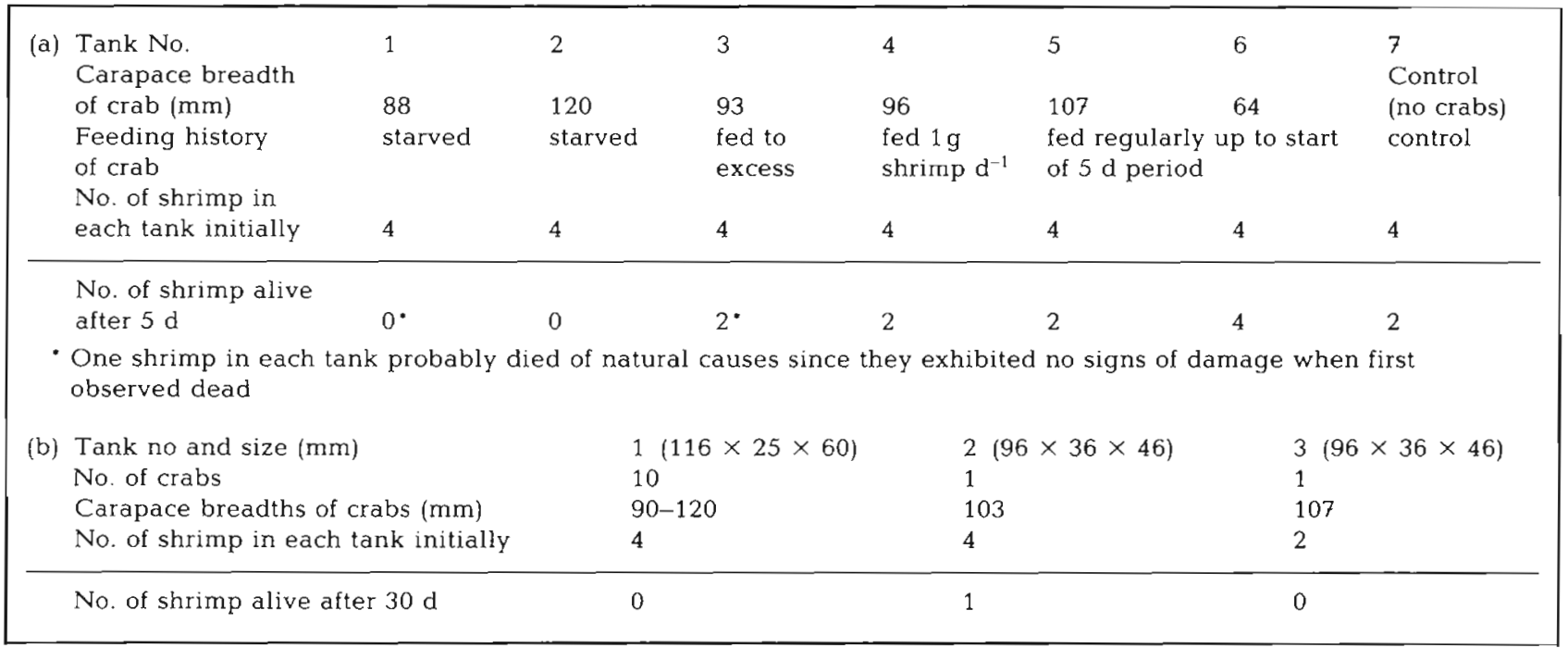

the most abundant mollusc in the foreguts at all stations, although at Tapo Agua Dulce the oyster Striostrea iridescens was also common. Penaeid shrimps made up a much smaller proportion of the food than either crabs or bivalves, except in the small sample from Tapo Botadero in which they constituted about $20 \%$ of the weight of food and were the most important identifiable food item apart from corophiid amphipods. At all stations the most common crabs in the diet were Callinectes sp., Cardisoma crassum and Gercarcinus sp. Some remains of Uca sp. Were found in foreguts of crabs from Tapo Agua Dulce. Fish were eaten at all stations and were important in the diet of crabs at Las Garzas and Tapo Agua Dulce. Polychaetes were only common in foregut samples from Tapo food items showed no apparent seasonal trend in foregut samples and generally were consumed in very small quantities throughout the whole period.

The diet of crabs of different sizes varied considerably (Table 5). Molluscs and crustaceans were generally most abundant in the foreguts of Callinectes arcuatus of over $60 \mathrm{~mm}$ carapace breadth but amphipods and cumaceans were also abundant in the foreguts of crabs below $60 \mathrm{~mm}$ in size. In Huizache, fish remains were most important in the diet of larger crabs but, in Caimanero, crabs of all sizes consumed similar quantities. Polychaetes and plant material were slightly more abundant in the foreguts of small crabs. The foreguts of smaller crabs contained much more sand and mud than those of larger crabs. 


\section{Predation on Live Shrimp and Feeding Activity}

In the first experiment crabs which had been starved killed and consumed all 4 shrimps in their tanks during the $5 \mathrm{~d}$ period (Table 6a). The mortality of shrimp in tanks containing non-starved crabs did not exceed that in the control tank, and only 2 shrimps were killed in these tanks. Tank 6, containing a juvenile crab of 64 mm carapace breadth, exhibited no shrimp losses at the end of the $5 \mathrm{~d}$ period. In the second experiment, conducted in larger tanks, the results were similar (Table 6b). With a high crab density, as in Tank 1, the shrimps were rapidly killed and at the end of Day 3 no shrimp remained. With lower crab densities, as in Tanks 2 and 3 , the shrimps were killed at a much slower rate and, in Tank 2, 1 shrimp remained alive at the end of $30 \mathrm{~d}$.

In total, 21 shrimps were killed and eaten by the crabs and, of these, 19 'kills' occurred during the night, mainly between 18:00 $\mathrm{h}$ and 21:00 h. The crabs always waited for the shrimps to approach very close to them before initiating an attack, and then, often partially buried in the sand, quickly lunged at the shrimp with their chelipeds. Most observed attacks were unsuccessful because, although the crabs often made contact with the shrimps, they appeared unable to close their claws quickly enough to seize and damage the shrimp before it escaped with a rapid jump. In one case, a crab made 37 unsuccessful attacks on a single shrimp. In successful attacks, the shrimps were generally seized by their antennae, telson or the underpart of their abdomen and then pulled down towards the crab's mouth parts. The crab then usually seized the shrimp behind the posterior margin of its carapace, severed it, and consumed the contents of the carapace before the abdomen. During daytime, and at night between 24:00 $h$ and 05:00 h, very few attacks were made by crabs on shrimp and both were often observed to be buried in the sand for long periods, frequently very close together. Between 05:00 h and 08:00 h more attacks were made but not as many as between 18:00 h and 21:00 h.

\section{DISCUSSION}

Both the gravimetric and frequency of occurrence analyses of foregut contents gave similar results except that the latter method tended to overestimate the importance of small animals occurring frequently, but only in small numbers in each foregut. Errors due to the accumulation of materials resistant to digestion, such as shell, bone and sand, were introduced by both methods $_{i}$ these are common criticisms of these methods of gut analysis (Hynes, 1950; Windell, 1968; Godfriaux, 1969 and Colman, 1972).
The analysis of foregut contents of Callinectes arcuatus and $C$. toxotes shows that they are primarily predators of sessile or slow moving benthic macroinvertebrates. Their diets were similar but that of $C$. arcuatus was more varied. The diet of $C$. toxotes comprised mainly of the clam Tagelus affinis and crabs were the only other important item in the diet of this species. C. arcuatus fed heavily on bivalves, crabs, fish and - to a lesser extent - on non-brachyuran decapods, plant material and polychaetes. A similar dietary difference between these 2 species was reported by Estevez (1972), but in the present study data were scarce for $C$. toxotes. Both species are also detritivores, consuming decaying plant debris and inorganic material, and scavengers, consuming fresh and decaying flesh of all kinds. Foraminiferans, bryozoans and hydrozoans were frequently found in foreguts in small quantities and it is probable that they are not selectively eaten but are coincidentally ingested with larger food items and detritus.

Estevez (1972) reported diets similar to those found in this study for Callinectes arcuatus and C. toxotes in Columbia, with bivalve molluscs (especially mytilids) the major food component. Furthermore, this type of diet has been widely reported for many large portunid crabs, including $C$. sapidus off the east coast of the United States (Darnell, 1958; Tagatz, 1968; Jaworski, 1972), C. latimanus in West African coastal lagoons (Kwei, 1974), Scylla serrata in South African and Australian waters (Hill, 1976) and Carcinus maenas on European and N. American shores (Muntz et al., 1965; Crothers, 1968; Ropes, 1969).

Although several authors have reported observing Callinectes sapidus eating living plants (Hay, 1905; Churchill, 1919; Truitt, 1939; Darnell, 1958) it is not known if Callinectes spp. can digest plant material. Carbohydrases have been detected in the stomach fluids of other portunid crabs, such as Carcinus maenas (Hylleberg-Kristensen, 1972), but it remains to establish whether the presence of plant material in the guts of $C$. arcuatus and $C$. toxotes indicates selective feeding by them on plant material, or merely the coincidental ingestion of such material with other food items. It is also possible that plant material from the digestive tracts of prey species is consumed during feeding

Differences in the contribution of food types different to the diet of Callinectes arcuatus in different areas of the lagoon system probably result from differences in prey availability. Ennis (1973) reported that the percentage occurrence of various prey species in lobster stomachs reflected the relative abundance of the prey species in the habitat. The same is true for $C$. arcuatus. Molluscs are more important in the diet of $C$. arcuatus in Caimanero than in Huizache because in the latter area they are much less abundant (Garcia-Cubas, 
1969; Edwards, 1978a) and are replaced in the diet of C. arcuatus in Huizache, to some extent, by crustaceans. Similarly, crabs in Estero Agua Dulce fed heavily on the oyster Striostrea iridescens, this estero being one of the few places in the lagoon system where oysters occur in large numbers. From all areas of the lagoon system the foreguts of $C$. arcuatus contained the remains of crabs. Callinectes spp. are very cannibalistic and feed on juvenile, moulting and unhealthy crabs of their own species (Benedict, 1940; Cargo and Cronin, 1951; Darnell, 1958). Cannibalism was found to be most common in $C$. arcuatus in areas such as Las Garzas where crab densities were high $\left(1 \mathrm{crab} \mathrm{m}^{-2}\right)$. In other areas, particularly near dense mangrove stands, Gecarcinus sp. and Cardisoma crassum were the most commonly preyed upon crabs

Seasonal changes in the diet of Callinectes arcuatus reflect changes in the availability of prey organisms throughout the year. Molluscs were a major component in the diet of $C$. arcuatus throughout the whole year in Caimanero but were most abundant in foregut samples from Huizache in the dry season. This may reflect a peak in mollusc abundance in Huizache or merely a peak in their availability to the crabs. Fish, penaeid shrimps and juvenile Callinectes were preyed upon most heavily during the dry season and early wet season which coincided with the period when they were at their maximum abundance (Edwards, 1978b; Warburton, 1978)

All sizes of Callinectes arcuatus consumed the same foods but in different proportions. Bivalves, gastropods, crabs, non-brachyuran decapods and fish were preyed upon most by crabs over $60 \mathrm{~mm}$ in carapace breadth. Fish remains were also common in the foreguts of smaller crabs in Caimanero but it is probable that this was due to their scavenging the remains of dead fish. Most crabs below $60 \mathrm{~mm}$ in breadth consumed polychaetes, plant material, amphipods, cumaceans, sand, mud, and detritus. At this size, they are predominantly detritivorous in their feeding habits, ingesting and triturating large amounts of substrate in the process, whilst the larger crabs are predominantly scavengers and predators.

Although fish are abundant in the lagoon system, and were commonly eaten by crabs, it is doubtful that Callinectes arcuatus can kill large and healthy fish. Hay (1905) and Truitt (1939) reported that $C$. sapidus frequently stalked fish and Kwei (1974) wrote that $C$. latimanus can stalk and kill Tilapiasp. Evidence from the present study and from laboratory observations indicates that, whilst $C$. arcuatus is capable of killing small or weak fish, it is most probable that much of the fish eaten by the crabs is through scavenging dead fish and waste products abundantly discarded by fishermen during the shrimp fishing season in areas near fishing villages. Similarly, C. arcuatus was found not to be an important predator on penaeid shrimp, and laboratory observations indicated that it was not a very efficient predator of highly mobile organisms such as shrimp, even in the confines of laboratory tanks. It is therefore more probable that the crabs affect penaeid shrimp by competition for food and space, rather than directly through predation; they occur in the same areas and during certain stages of their life cycles utilize the same food sources.

Feeding in Callinectes arcuatus probably occurs throughout the day at low levels, since foreguts sampled at all times of day invariably contained some food. Laboratory observations revealed that soft organic tissue was almost completely evacuated from the foregut within $6 \mathrm{~h}$ of feeding and hence the presence of such material is indicative of fairly recent food intake. Laboratory experiments indicated that feeding activity was greatest at night, especially just after dusk and to a lesser extent around dawn, as has been reported for $C$. latimanus (Kwei, 1974) and C. sapidus (Lambou, 1952; Darnell, 1958).

Callinectes arcuatus and $C$. toxotes are large crabs which have successfully invaded estuaries and lagoons on the Pacific coasts of Mexico, Central and South America. Their large size and abundance makes them important predators of molluscs and crustaceans and their predatory activities may determine the distribution of prey species as reported for crabs in British waters (Muntz et al., 1965). Both species include detrital material in their diets and feed heavily on other organisms which are dependent on detrital breakdown. It is therefore possible that the distribution of these crabs may be limited locally by that of their prey species, which would explain their general absence in areas near the fringes of the lagoons and in the river mouths where detritus and detritus feeding organisms are scarce. Norse and Estevez (1977) suggested that, seaward of estuaries, these species would be at a disadvantage in competition with shelf species which are capable of living at lower food densities, and which exhibit higher foraging, assimilation or growth efficiencies.

Acknowledgements. The author is grateful to Drs. A. Ramirez, A. Ayala and A. Laguarda for the provision of laboratory facilities, to Professor E. Naylor, Dr D. I. Williamson and Mr A. B. Bowers for help and supervision, and to the British Council for local support. Financial support was provided by the Overseds Development Administration, London and CONACYT, MeXico

\section{LITERATURE CITED}

Benedict, S. (1940). Soft crab and hard La Conserv Rev 9 (1): $11-14$ 
Cargo, D. G., Cronin, L. E. (1951). The Maryland crab industry in 1950. Contr Chesapeake biol. Lab. 92: 1-23

Churchill, E. P. (1919). Life history of the blue crab. Bull. Bur Fish., Wash. 36: 95-129

Colman, J. A. (1972). Food of Snapper, Chrysophrys auratus (Forster), in the Hauraki Gull, New Zealand. N. Z. Jl mal Freshwat. Res. 6 (3): 221-239

Crothers, J. H. (1968). The biology of the shore crab, Carcinus maends (L). 2. The life history of the adult crab. Fld Stud. 2 (5): $579-614$

Damell, R. M. (1958). Food habits of fishes and larger invertebrates of Lake Pontchartrain, Loussiana, an estuarine community. Publs Inst. mar Sci. Univ. Tex. 5: 3.5.3-416

Edwards, R. R. C. (1977). Field experiments on growth and mortality of Penaeus vannamei in a Mexican coastal lagoon complex. Estuar. coast. mar Sci. 5: 107-121

Edwards, R. R. C. (1978a). Ecology of a coastal lagoon complex in Mexico. Estuar coast. mar Sci. 6: 75-92

Edwards, R. R. C. (1978b). The fishery and fisheries biology of penaeid shrimp on the Pacific coast of Mexico. Oceanogr mar Biol. Rev. 16: 145-180

Ennis, G. P. (1973). Food, feeding and condition of lobsters, Homarus americanus, throughout the seasonal cycle in Bonavista Bay, Newfoundland. J. Fish. Res. Bd Can. 30: 1905-1909

Estevez, M. (1972). Estudio preliminar sobre la biologia de dos especies alopatricas de cangrejos brachyrhyncha del Pacifico Colombiano. Boln Mus. Mar Bogota 4: 1-17

Fernandez, H. R. (1973). Sensitivity and visual pigments of the compound eye of the galatheid crab Pleuroncodes planipes. Mar Biol. 20: 148-153

Garcia-Cubas, A. (1969). Resultados preliminares del estudıo de los moluscos en las lagunas de Caimanero y Huizache, Sinaloa y Yavaros, Sonora. Boln. Inst. Geol. Univ. Nac. Auton. Mex. 1969: 115-134

Godfraux. B. L. (1969). Food of predatory demersal fish in Hauraki Gulf: I. Food and feeding habıts of Snapper. N. Z Jl mar Freshwat. Res. 3: 518-544

Goldsmith, T H., Fernandez, H. R. (1968). Comparative studies of crustacean spectral sensitivity. Z. vergl. Physiol (2): $156-175$

Hay, W. P. (1905). The life history of the blue crab (Callinectes sapidus). U.S. Comnl. Fish. Rep. (1904), Appendix, $395-413$

Hill, B. J. (1976). Natural food, foregut clearance rate and activity of the crab Scylla serrata. Mar Biol. 34 109-116

Hylleberg-Kristensen, J. (1972). Carbohydrases of some marine invertebrates with notes on their food and on the natural occurrence of the carbohydrasos studied. Mar Biol. 14: 130-142

Hynes, H. B. N. (1950). The food of freshwater sticklebacks (Gasterosteus aculeatus and Pygosteus pungitius) with a review of the methods used in the studies of food of fushes J. Anim. Ecol. 19: 36-58

Jaworski, E. (1972). The blue clab fishery, Baratarla Estuary Louisiana. Publ. LSU-SG-72-01, Centre for Wetlands Resources, Louisiana State Uni., Baton Rouge, La., 1-112

Kwei, E. A. (1974). Coastal lagouns in Ghand and the ecology of the blue crab. Cailinectes latimanus (Rathbun). Ph. D thesis, Faculty of Science, University Ghana, Lecon

Lambou, $V$ W. (1952). Food and habitat of garfish in the tidewater of southeastern Louisiana. M. So thesis, Louisiana State University, Baton Rouge, La

Muntz, L., Ebling, F. J., Kitching, J. A. (1965). The ecology of Loch Ine. XIV. Predatory activities of large crabs. J. Anim. Ecol. 34: 315-329

Norse, E. A., Estevez, M. (1972). Studies on portunid crabs from the Eastern Pacific. I. Zonation along environmental stress gradients from the coast of Columbar. Mar. Biol. 40: 365-373

Paul, R. K. G. (in press). Abundance, breeding and growth of Callinectes arcuatus Ordway and Callinectes toxotes Ordway (Decapoda, Brachyura, Portunidae) in a lagoon complex on the Mexican Pacific Coast. Estuar. coast. Shelf Sci.

Ropes, J. W. (1969). The feeding habits of the green crab. Carcinides maenas (L). Fish. Bull. Fish. Wildl. Serv. U.S. $67(2): 183-203$

Steigenberger, J. A., Larkin, P. A. (1974). Feeding activity and rates of digestion of northern squawfish (Ptychocheilus). J. Fish. Res. Bd Can. 31:411-420

Tagatz. M. E. (1968). Biology of the blue crab, Callinectes sapidus Rathbun, in the St. John's River, Florida. Fish. Bull. Fish. Wildl. Serv. U.S. 67 (1): 17-33

Truitt, R. V (1939). The blue crab. In: 'Our water resources and their conservation'. Contrib. Chesapeake biol. Lab. 27: $10-38$

Warburton, K. (1978). Community structure, abundance and diversity of fish in a Mexican coastal lagoon system. Estuar coast. mar Sci. 7. 497-519

Warburton, K. (1979). Growth and production of some important species of fish in a Mexicon coastal lagoon system. J. Fish. Biol. 14: 449-464

Windell, J. T (1968). Food analysis and rate of digestion. In: Ricker, W E. (ed.) Methods for assessment of fish production in freshwaters. IBP Handbook No. 3: 216-226 